DOI: $10.19195 / 2084-5065.43 .9$

\title{
Tożsamość czynu jako podstawa różnicowania mechanizmów redukujących odpowiedzialność karną
}

\author{
JACEK GIEZEK \\ Katedra Prawa Karnego Materialnego \\ Uniwersytet Wrocławski
}

I. Czyn jako podstawa odpowiedzialności karnej w zasadzie niemal od zawsze znajdował się w centrum zainteresowań nauki prawa karnego ${ }^{1}$. Na jego temat zarówno w bliższej, jak i dalszej przeszłości napisano już tak wiele, że niezwykle trudno o spojrzenie zupełnie świeże, które wolne byłoby od zarzutu, że w kolejnym opracowaniu nie powiedziano niczego, co nie zostałoby powiedziane już

${ }^{1}$ W okresie powojennym na temat pojęcia czynu w polskiej literaturze prawa karnego wypowiadano się wielokrotnie. Jedynie tytułem przykładu wskazać można szereg następujących prac: W. Wolter, O czynie ludzkim jako działaniu lub zaniechaniu przestępnym, PiP 1956, z. 5-6; idem, Kumulatywny zbieg przepisów ustawy, Warszawa 1960; idem, Reguty wyłaczania wielości ocen w prawie karnym, Warszawa 1961; Z. Ziembiński, Analiza pojęcia czynu, Warszawa 1972; A. Spotowski, Pomijalny (pozorny) zbieg przepisów ustawy i przestępstw, Warszawa 1976; M. Tarnawski, Zagadnienia jedności i wielości przestępstw, Poznań 1977; I. Andrejew, O pojęciu czynu w prawie karnym, „Studia Filozoficzne” 1985, nr 2-3; W. Mącior, Czyn ludzki i jego znaczenie w prawie karnym, Warszawa 1990; T. Kaczmarek, Spory wokót pojęcia czynu i ich znaczenie dla systemowego objaśniania struktury przestęstwa, [w:] Problemy odpowiedzialności karnej. Księga ku czci profesora Kazimierza Buchaty, red. Z. Ćwiąkalski et al., Kraków 1994; P. Kardas, J. Majewski, Kilka uwag w kwestii tzw. rzeczywistego zbiegu przepisów ustawy w prawie karnym oraz sposobach jej rozstrzygania, [w:] Problemy odpowiedzialności...; M. Rodzynkiewicz, Treść pojęcia „,czynu” jako efekt procedury modelowania, [w:] Problemy odpowiedzialności...; M. Dąbrowska-Kardas, P. Kardas, Czyn ciagly i ciag przestepstw. Komentarz do art. 12 i art. 91 k.k. z 1997, Kraków 1999; P. Konieczniak, Czyn jako podstawa odpowiedzialności w prawie karnym, Kraków 2002; Ł. Pohl, Zbieg przepisów ustawy i zbieg przestępstw - próba uporządkowania pojęć, RPEiS 2005, z. 1; J. Giezek, Zbieg przepisów a konstrukcja przestępstwa ciagtego, [w:] Zbieg przepisów i zbieg przestepstw w polskim prawie karnym, Materiały II Bielańskiego Kolokwium Karnistycznego, red. J. Majewski, Toruń 2006; J. Majewski, „Ten sam czyn” jako jedna z przesłanek kumulatywnej kwalifikacji, [w:] Zbieg...; P. Kardas, Zbieg przepisów ustawy w prawie karnym. Analiza teoretyczna, Warszawa 2011. 
wcześniej. Czy zatem rozważaniami na temat czynu warto zaprzątać uwagę potencjalnego czytelnika? Otóż usprawiedliwieniem ich podejmowania może być ciągle jeszcze obecna bezradność przy wyznaczaniu tego, co składa się — z jednej strony — na ontologię zjawiska nazywanego czynem, z drugiej zaś — nadaje mu normatywny kształt, będący wynikiem przyjęcia określonej konwencji ${ }^{2}$. Intrygujące jest także pytanie, dlaczego tak bardzo koncentrujemy się na wytyczaniu granic czynu, a jednocześnie postrzegamy go jako niedający się niczym zastąpić fundament, na którym nabudowywane są normatywne kryteria odpowiedzialności karnej. Rzecz przy tym znamienna, że już na płaszczyźnie czynu próbujemy wiązać ontyczne oraz normatywne podstawy odpowiedzialności, dostrzegając — skądinąd trafnie — że z jednej strony pociągany do niej podmiot zachowuje się przecież w jakiś dający się obiektywnie opisać sposób, a jednocześnie — z drugiej strony - na podstawie tego zachowania trzeba wykreować odpowiednio ukształtowany obiekt prawnokarnego wartościowania, który moglibyśmy nazwać czynem ${ }^{3}$.

Gdy mówimy o tzw. ontologicznej podstawie czynu polegającego na działaniu, mamy z reguły na myśli ludzkie zachowanie, które — nawet gdyby zrezygnować w tym miejscu z jakiejkolwiek bliższej jego charakterystyki — jest zapewne jakimś kompleksem ruchów fizycznych. Owa fizyczność zachowania to podstawa czynu, której nie da się sensownie zakwestionować, jeśli odpowiedzialności karnej nie będziemy chcieli przenieść w sferę wirtualnej rzeczywistości. Realność (obiektywność) ludzkiego zachowania wyraża się chociażby w tym, że można ją stwierdzić w sposób czysto zmysłowy i opisać w kategoriach pojęć fizycznych ${ }^{4}$. Jeśli człowiek macha ręką lub nogą, to niezależnie od tego, co to machanie miałoby oznaczać, każda osoba obserwująca takiego człowieka - chociażby pochodziła z zupełnie innego kręgu kulturowego i zupełnie nie rozumiała znaczenia dostrzeżonej aktywności — wykonywanie tego rodzaju ruchów co najmniej na poziomie sensorycznym bez wątpienia zauważy. W tym właśnie sensie machanie ręką lub nogą istnieje obiektywnie i jest niezależne od jakiegokolwiek wartościowania. Nie trzeba również żadnej teorii, aby stwierdzić, że ma (lub miało) ono miejsce. Jeśli jednak aktywność tego rodzaju chcielibyśmy nieco lepiej zrozumieć, a w każdym razie nie ograniczać się do jej wymiaru często fizycznego, to powinniśmy zapew-

${ }^{2}$ Wypowiadając się na temat czynu jako podstawy odpowiedzialności karnej, Profesor Tomasz Kaczmarek już przed laty trafnie zauważył, że podejmowane — zresztą nie tylko w polskiej nauce prawa karnego - próby wyjaśnienia istoty tego pojęcia wymagają kompromisu wyrażającego się w odpowiednim uwzględnieniu dwóch skrajnie przeciwstawnych orientacji — ontologizującej oraz normatywizującej. Zob. T. Kaczmarek, Metodologiczne aspekty sporów wokót pojęcia czynu w polskim prawie karnym, [w:] Rozważania o przestępstwie i karze. Wybór prac z okresu 40-lecia naukowej twóroczości, Warszawa 2006, s. 43.

3 Pojawiają się wówczas dwa zasadnicze pytania: a) o kryteria, wedle których określana byłaby istota czynu, oraz b) o kryteria będące podstawą wyznaczania jego granic.

4 Abstrahuję tutaj oczywiście od rozmaitych rozważań i koncepcji filozoficznych kontestujących realność otaczającego nas świata. 
ne rozpoznać jego kontekst psychologiczny i/lub socjologiczny. Jest oczywiste, że wypada wówczas sięgnąć do nauk, które zajmują się interpretacją ludzkiego zachowania, czyli przede wszystkim właśnie do psychologii oraz socjologii. Z tej pierwszej dziedziny dowiadujemy się wiele o jednostkowym ludzkim zachowaniu, przy czym wiedza ta ma charakter zarówno empiryczny i jest wynikiem rozmaitych obserwacji, jak i teoretyczny, gdyż jej źródłem jest też interpretacja tego, co udało się zaobserwować. Socjologia pozwala natomiast na uwzględnienie społecznych interakcji, jakie towarzyszą każdemu prawnokarnie relewantnemu zachowaniu.

Rezygnując $\mathrm{w}$ tym miejscu z prezentowania rozmaitych koncepcji psychologicznych dotyczących istoty i struktury ludzkiego zachowania - do czego piszący te słowa nie ma zresztą wystarczających kompetencji — warto byłoby jednak przywołać jeden z dość dobrze utrwalonych oraz chętnie wykorzystywanych, również przez prawników, podziałów wszystkich przejawów aktywności na takie, które mają charakter wyłącznie reaktywny, oraz zachowania celowe, przy czym od razu należy zaznaczyć, że podział ten stanowi jedynie ilustrację prezentowanego tutaj problemu. Otóż zachowanie reaktywne to - jak twierdzą psychologowie najprostsza forma regulacji stosunków człowieka z jego otoczeniem, której przebieg w decydujący sposób wyznaczany jest przez bodźce. Tymczasem struktura zachowania celowego jest o wiele bardziej złożona, albowiem jego istotną cechę stanowi ukierunkowany przebieg, wiążący się z antycypacją pożądanego stanu rzeczy, do jakiego doprowadzić ma zaplanowana przez podmiot aktywność 5 .

Wracając w tym kontekście do przedstawionego przykładu człowieka machającego ręką, moglibyśmy powiedzieć, że może być ono np. reakcją na bodziec wynikający z utraty równowagi spowodowanej pośliźnięciem się na oblodzonym chodniku, a wówczas ma strukturę zachowania reaktywnego, lecz może być także zmierzającym do wywołania uszczerbku na zdrowiu innej osoby uderzaniem jej w głowę, a wtedy aktualizuje się struktura zachowania celowego. Jeśliby zarówno próbujący odzyskać równowagę, jak i zachowujący się w sposób celowy swym machnięciem ręką wywołał podobnych rozmiarów obrażenia ciała innej osoby, to powstać musiałoby pytanie, czy w obu przypadkach powinna się zaktualizować jego odpowiedzialność karna. Łatwo zauważyć, że w przedstawianej tutaj sytuacji mamy już do czynienia z dwojakiego rodzaju wartościowaniem. Pierwszy jego rodzaj lub poziom ma jednak jeszcze charakter naukowy, a w każdym razie nadaje się do zweryfikowania, albowiem przebiega na płaszczyźnie rozważań dotyczących poprawności koncepcji psychologicznej, wedle której ludzkie zachowania dzielą się na reaktywne oraz celowe. Rzecz oczywiście w tym, że to nie prawnicy będą dokonywać tego rodzaju weryfikacji, gdyż wymaga ona kompetencji

${ }^{5} \mathrm{Na}$ temat struktury i organizacji zachowań reaktywnych i celowych zob. T. Tomaszewski, Podstawowe formy organizacji i regulacji zachowania, [w:] Psychologia, red. T. Tomaszewski, Warszawa 1978, s. 497 n. 
w zupełnie innej dziedzinie wiedzy oraz co więcej może zostać przeprowadzona także za pomocą metod empirycznych. Prawo nie ma możliwości wpływania na strukturę zachowania celowego lub reaktywnego. Właściwości, którymi takie zachowania się charakteryzują, są obiektywnej natury i żadną decyzją, w tym także decyzją prawodawcy, zmienić ich niepodobna.

Drugi poziom wartościowania jest natomiast dokonywany ze znacznie dla prawnika bliższej, chciałoby się powiedzieć — czysto jurydycznej, perspektywy i sprowadza się do odpowiedzi na pytanie, czy oba rodzaje zachowań mogą być przedmiotem zainteresowania na płaszczyźnie prawa karnego, a mówiąc nieco ściślej — czy każde z nich chcielibyśmy nazwać czynem podlegającym prawnokarnemu wartościowaniu. Przyjmując określoną konwencję, prawnicy mogą wszak umówić się co do tego - czym zresztą już od dawna bardzo chętnie się zajmują - że tylko w zachowaniach celowych należy się dopatrywać istoty czynu jako podstawy odpowiedzialności karnej, odmawiając jednocześnie takiego statusu zachowaniom reaktywnym. Konwencjonalność takiego ujęcia - wynikająca z przyjmowania określonej aksjologii, a być może także z tego, jak rozumiana jest norma wyrażająca zakaz lub nakaz określonego zachowania — jawi się jako oczywista. O tym, że z ontologią tak sformułowane pytanie ma raczej niewiele wspólnego, nie trzeba chyba nikogo przekonywać, albowiem nie ma żadnych obiektywnych (,przyrodniczych”) podstaw, które pozwalałyby nam przyjąć, że czynem może być np. wyłącznie zachowanie celowe, bo wynika to z jego istoty. Równie dobrze moglibyśmy przecież uznać, że sprawca szkody przyczynowo wywołanej zachowaniem reaktywnym także dopuszcza się czynu, który chcielibyśmy poddać prawnokarnemu wartościowaniu, co innymi słowy oznaczałoby, że godzimy się na konwencję pozwalającą na formułowanie prawnokarnych ocen również w odniesieniu do czysto zewnętrznych przejawów aktywności podmiotu, w skrajnych przypadkach całkowicie wypreparowanych z elementu subiektywnego. Jeśli jednak tego nie czynimy, to przede wszystkim dlatego, że za tym, aby wyłącznie zachowania mające strukturę zachowań celowych traktować jako stanowiące podstawę prawnokarnego wartościowania czyny, przemawiają najbardziej podstawowe zasady nowożytnego prawa karnego. $Z$ zasadami tymi trudno natomiast pogodzić odpowiedzialność karną za wywołujące negatywny skutek zachowanie, które nie zmierza do żadnego celu, lecz jest jedynie reakcją na bodziec. Rzecz jednak w tym, że nie ma to już nic wspólnego z jego ontologiczną strukturą.

Rozważając, dlaczego w zachowaniu reaktywnym nie dopatrujemy się walorów czynu, warto również sięgnąć do argumentacji jurydycznej, już od dawna podnoszonej w nauce prawa karnego. Otóż w analizach teoretycznoprawnych dość zgodnie przyjmuje się, iż czyn, o którym mielibyśmy powiedzieć, że jest bezprawny, gdyż narusza normę wyrażającą zakaz/nakaz określonego zachowania, wiążemy z dwoma warunkami, tj. warunkiem wykonalności oraz dowolności zewnętrznego zachowania. Przez część doktryny prezentowany jest pogląd, 
że wykonalność oraz dowolność to elementy wyznaczające zakres zastosowania normy sankcjonowanej ${ }^{6}$. Trafne wydaje się w tym kontekście twierdzenie, że zakres zastosowania norm wyznaczony jest $\mathrm{z}$ jednej strony konwencjonalnie (przez prawodawcę), z drugiej zaś - naturalnie (przez okoliczności, w których spełnienie danej normy w ogóle nie jest możliwe) ${ }^{7}$. Wykonalność i dowolność to oczywiście — w pewnym sensie — także ontologiczna baza ludzkiego zachowania, skoro można ją weryfikować lub falsyfikować w kategoriach ,prawda-fałsz”. Prawdą jest, że „człowiek musi oddychać, aby żyć”, tak jak nieprawdziwe byłoby stwierdzenie, że „człowiek zdolny jest do podniesienia własnymi siłami ciężaru ważącego tysiąc kilogramów”. Bezsensowny byłby zatem zakaz oddychania lub nakaz podniesienia tak ogromnego ciężaru. Racjonalność ujętych w taki sposób norm (zakazującej lub nakazującej) nie zależy jednak od żadnej oceny, lecz jest efektem uwzględnienia lub zlekceważenia realiów otaczającego świata. Nie możemy także zapominać o tym, że dowolność i wykonalność nie stanowią wyłącznie atrybutów zachowań bezprawnych, lecz również takich, które oceniamy jako szlachetne, bohaterskie czy pożądane. Nie nazwiemy wszak bohaterem człowieka, który spadając z wysokości, masą własnego ciała pozrywał przewody podłączone do ładunku wybuchowego, który terroryści zamierzali właśnie zdetonować, co kauzalnie przyczyniło się do uratowania setek istnień ludzkich.

Trudno również nie zgodzić się ze stwierdzeniem, że skoro norma sankcjonowana ma na celu określenie powinnego, tj. nakazanego lub zakazanego zachowania, to sensowne ustanowienie tej normy odnosić się może wyłącznie do sytuacji, w których nakazane lub zakazane zachowanie jest zależne od woli podmiotu, będącego jej adresatem. Oznacza to, że zachowania pozbawione cechy dowolno-

${ }^{6} \mathrm{~W}$ rozważaniach z zakresu teorii norm przedmiotem sporu jest usytuowanie warunku wykonalności czynu w strukturze norm sprzężonych, który bywa umieszczany albo w zakresie zastosowania normy sankcjonowanej, albo w zakresie jej normowania. W pierwszym z wymienionych zakresów warunek ten umieszcza $Ł$. Pohl (op. cit., s. 79), twierdząc jednocześnie, że w konsekwencji warunek wykonalności, jaki stawia się normowanemu zachowaniu, odrywa się od czynu. Autor ten dostrzega jednocześnie, że tradycyjna metoda prawnokarnego wartościowania prowadzi do ustalenia, że to właśnie dany czyn jest albo nie jest wykonalny, co mogłoby sugerować, że warunek wykonalności powinien być umieszczany wespół z czynem w zakresie normowania normy sankcjonowanej. Z kolei P. Kardas twierdzi, że wykonalność czynu stanowi jeden z elementów wyznaczających zakres zastosowania normy sankcjonującej powodujący, że gdy w jakimś konkretnym układzie sytuacji nakazywany czyn okazuje się niemożliwy do spełnienia, to należy przyjąć, iż pozytywny zakres normowania ustanowionej normy został w odpowiedniej części co do takich sytuacji zawężony. Zob. P. Kardas, O relacjach między struktura przestępstwa a dekodowanymi z przepisów prawa karnego strukturami normatywnymi, CzPKiNP 2012, nr 4, s. 50. Nie podejmując $\mathrm{w}$ tym miejscu próby rozstrzygnięcia pojawiającego się dylematu, jedno można chyba stwierdzić z całą pewnością, a mianowicie że warunek wykonalności stanowi kryterium, od którego spełnienia zależy, czy zachowanie może zostać objęte zakazem lub nakazem określonym w normie sankcjonowanej.

7 Tak np. M. Dąbrowska-Kardas, Analiza dyrektywalna przepisów części ogólnej kodeksu karnego, Warszawa 2012, s. 175. 
ści nie mogą stanowić przedmiotu racjonalnie kształtowanego zakazu lub nakazu o jednoznacznie sterującej funkcji, którego celem jest skłonienie określonego adresata do zachowania pozostającego w zgodzie ze wskazaniami (dyrektywami) prawodawcy ${ }^{8}$. Jest poniekąd nawet banalnie oczywiste, że o normie postępowania tylko wtedy da się powiedzieć, że wpływa ona na zachowanie, gdy jej adresat dysponować będzie możliwością dokonania wyboru. Rzecz bowiem w tym, że dogmatyka prawa - realizując swe podstawowe zadanie, którym jest ustalenie, jakie normy obowiązują (w obrębie danego systemu) i jaka jest ich treść — opiera się na założeniu, często expressis verbis niewysłowionym, iż prawodawca jest pod każdym względem (doskonale) racjonalny, tj. cechuje się racjonalnością językową, socjotechniczną, prakseologiczną, aksjologiczną itp. Z założenia o racjonalności prawodawcy wynika zaś szereg konsekwencji.

W szczególności wynika z niego, że prawodawca nie ustanawia norm, które nie nadają się do kierowania postępowaniem podmiotów podległych danemu systemowi prawa. Takimi normami byłyby przykładowo normy o pustym zakresie adresatów albo pustym zakresie zastosowania, normy nakazujące czynienie rzeczy niemożliwych, a także normy niezgodne z tymi normami. Uchybiałoby postulatowi racjonalności prawodawcy, gdyby chciał on spełnienia normy, o której wiadomo z góry, że nigdy nie znajdzie zastosowania, lub też normy, która wyznacza swym adresatom zachowania niemożliwe9

Prowadzi to do wniosku, że norma może się odnosić do takich jedynie zachowań, którymi jej adresat może swobodnie pokierować ${ }^{10}$. Powtórzmy zatem raz jeszcze - norma sankcjonowana wyraża dwa istotne z punktu widzenia odpowiedzialności warunki, a mianowicie warunek dowolności oraz wykonalności objętego jej treścią zachowania ${ }^{11}$.

${ }^{8} \mathrm{Na}$ zasadność powiązania kryterium dowolności z płaszczyzną bezprawności, a więc normą sankcjonowaną, wskazuje także J. Majewski, Prawnokarne przypisywanie skutku przy zaniechaniu, Kraków 1997, s. 38. Trzeba jednak dodać, że autor ten nie wyklucza również powiązania warunku dowolności zachowania z płaszczyzną winy.

9 J. Majewski, Tak zwana kolizja obowiązów w prawie karnym, Warszawa 2002, s. 104.

${ }^{10}$ Na dowolność zachowania jako warunek sine qua non przyjęcia samego czynu jako podstawy odpowiedzialności karnej już przed laty wskazywał A. Zoll, Polecenie służbowe jako element kształtujacy odpowiedzialność karna, Pal. 1986, z. 4, s. 52. Wśród autorów najmłodszego pokolenia na wymienione tu cechy czynu wskazuje m.in. S. Tarapata, Dobro prawne w strukturze przestępstwa, Warszawa 2016, s. 191 n., dochodząc jednocześnie do wniosku, który z punktu widzenia formułowanego dalej postulatu odnoszącego się do podstaw mechanizmów redukcyjnych gotów byłbym uznać za interesujący, że uznawanie zachowania określonego podmiotu za czyn będący odrębnym elementem struktury przestępstwa jest zbędne, gdyż cechy te (m.in. wykonalność oraz dowolność) mogą równie dobrze zostać umieszczone na płaszczyźnie bezprawności.

11 Inaczej kwestię tę postrzega $Ł$. Pohl, zgłaszając — jak to określa — pomysł korekty polegającej na przesunięciu warunku dowolności zachowania z zakresu normowania prawnokarnej normy sankcjonowanej do zakresu zastosowania normy ją sankcjonującej. Otrzymujemy wtedy — zdaniem tego autora — rozwiązanie teoretyczne odpowiadające intuicjom wyrażonym w karnistyce. „Z jednej bowiem strony dopuszcza ono możliwość przekroczenia normy sankcjonowanej 
Nie tracąc przeto z pola widzenia — także w kontekście przywołanych tutaj wypowiedzi - że czyn określany jest zazwyczaj jako zachowanie psychicznie sterowane, a jednocześnie dowolne oraz zależne od woli adresata normy prawnej, zauważymy od razu, że trudno byłoby go ujmować w sposób czysto przedmiotowy, w oderwaniu od stanu świadomości zachowującego się w określony sposób podmiotu, albowiem skoro tylko zachowania dowolne stanowić mogą przedmiot nakazu lub zakazu, to w rezultacie — bez uwzględnienia elementu subiektywnego, odzwierciedlającego stan świadomości sprawcy dokonującego wyboru określonej aktywności - nie da się ich usytuować w strukturze normy sankcjonowanej. Bezsensowne byłoby zatem zakazywanie czysto zewnętrznego zachowania (a więc takiego, które - patrząc z perspektywy psychologicznej — nie spełnia kryteriów zachowania celowego), jeśli przedmiot racjonalnie skonstruowanego zakazu ma być postrzegany jako coś więcej niż będący reakcją na bodziec kompleks ruchów fizycznych ${ }^{12}$.

Jeśli jednak prawnokarnie relewantnym czynem nie może się stać zachowanie, którym człowiek nie zdołałby pokierować, czyli — innymi słowy — zachowanie niesterowalne, a więc $\mathrm{w}$ istocie takie, którego wykonania nie można by ani nakazać, ani zabronić, to - patrząc z takiej, rzec można jurydycznej, perspektywy — statusu czynu nie nadamy zachowaniu reaktywnemu, będącemu przecież właśnie niesterowalną reakcją na bodziec, którą nie sposób pokierować inaczej, niżby to wynikało ze stymulacji z bodźca wynikającej. O ile jednak nie da się zakazać zachowania reaktywnego, o tyle można zakazać tego, aby człowiek nie zmierzał w kierunku celu, którego realizacja wiąże się z wywołaniem zagrożenia dóbr przedstawiających wartość społecznie doniosłą ${ }^{13}$. Przy założeniu, że ludzka aktywność, stanowiąca pewne continuum ${ }^{14}$, to splot różnie układających się oraz przeplatających wzajemnie zachowań celowych i reaktywnych, skłonni będziemy więc przyjąć, że na płaszczyźnie prawa karnego interesować nas będą jedynie te

zachowaniem niedowolnym, a z drugiej strony ustalenia o dowolności i niedowolności wartościowanego zachowania sytuuje w zakresie zastosowania odpowiednich norm nakazujących prawnokarne reakcje”. Ł. Pohl, Struktura normy sankcjonowanej w prawie karnym, Poznań 2007, s. 82.

12 Trafne jest zatem twierdzenie, że zachowanie człowieka musi charakteryzować się zdolnością dopasowania ruchów do potrzeb realizacji wyobrażonego celu. Zob. M. Królikowski, Kontekstowa teoria (dogmatyki) prawa karnego, „Studia Iuridica” 2006, nr 46, s. 197 n.

13 Podkreślić zatem raz jeszcze należy, że zakaz ma sens, jeśli podmiot jest w stanie uczynić mu zadość. Wracając do przytoczonego przykładu, zauważymy, że nie da się racjonalnie zakazać utraty równowagi na oblodzonym chodniku, natomiast można uczynić przedmiotem zakazu wchodzenie na oblodzony chodnik.

14 Warto już w tym miejscu zaznaczyć, że continuum definiowane jest zazwyczaj jako ciągły, uporządkowany zbiór nieskończonej liczby elementów przechodzących płynnie jeden w drugi. Nie ulega raczej wątpliwości, że jeżeli tak rozumianym continuum miałoby być ludzkie zachowanie, to owej ciągłości — złożonej z najróżniejszych zlewających się z sobą przejawów aktywności i bierności, a więc oznaczającej nieustanne płynne przechodzenie jednego stanu rzeczy w drugi — nie da się uniezależnić od osi czasu. 
fragmenty owego continuum, które mają strukturę zachowania celowego i tylko do nich odnosić będziemy pojęcie „czyn”.

Ontologia tak rozumianego zachowania - co starano się zasygnalizować jest jednak o tyle złożona, że — z jednej strony — obiektywny oraz niezależny od jakichkolwiek zdeterminowanych teoretycznie lub kulturowo zapatrywań jest zapewne kompleks ruchów fizycznych, choć jednocześnie — z drugiej strony nawet jeśli ich charakter oraz ujmowanie w ramy reaktywności lub celowości nadaje się do empirycznej weryfikacji - nie da się tutaj uniknąć rozmaitych wartościowań, zmierzających chociażby do wykazania, że tylko zachowanie celowe (a więc psychicznie sterowane oraz będące wyrazem wolnej woli) może stanowić przedmiot prawnokarnego wartościowania.

Prowadzi to do wniosku, że odpowiedź na pytanie „co to jest czyn?” - sprowadzające się w istocie do rozstrzygnięcia kwestii jakościowej, dającej się wyrazić w nieco precyzyjniej sformułowanym pytaniu: ,jakie zachowania podmiotu mogą zostać potraktowane jako mające cechy charakterystyczne dla aktywności nazywanej czynem?" - na płaszczyźnie czysto ontologicznej udzielona być, niestety, nie może ${ }^{15}$. W gruncie rzeczy mamy zatem do czynienia $\mathrm{z}$ dość rzadko dostrzeganym swoistym odwróceniem relacji, co dałoby się wyrazić w następujący sposób: określone zachowanie spełnia podstawowy warunek, aby stać się potencjalnym przedmiotem zakazu, nie dlatego że stanowi ono czyn, lecz — odwrotnie — dlatego urasta do rangi czynu, że można go zakazać. To nie obiektywne, psychofizyczne właściwości zachowania, lecz możliwość sterowania tymże zachowaniem za pomocą zakazu lub nakazu zawartego w normie decydują o tym, że spełnia ono kryteria, dzięki którym możemy je nazwać czynem. Mówiąc zaś jeszcze inaczej — w pierwszej kolejności dążymy do ustalenia, jakim cechom odpowiadać powinno ludzkie zachowanie, abyśmy mogli rozważać poddanie go prawnokarnemu wartościowaniu, a dopiero w przypadku odpowiedzi pozytywnej, czyli mającego kryminalnopolityczny charakter rozstrzygnięcia, że określone zachowanie nadaje się do tego rodzaju wartościowania, „etykietujemy” je jako czyn.

II. Jednym z fundamentalnych pytań, jakie stawiane są przy konstruowaniu oraz badaniu podstaw odpowiedzialności karnej — a więc zarówno w perspektywie dogmatycznej, jak i z punktu widzenia praktyki wymiaru sprawiedliwości — jest pytanie o tożsamość czynu jako fragmentu ludzkiego zachowania podlegającego prawnokarnemu wartościowaniu. W przeszłości na to pytanie próbowano

15 Rację ma J. Majewski, gdy twierdzi, że nie istnieje jakiś ,,jedynie prawdziwy” model czynu, do którego odkrycia należałoby dążyć. Możliwych jest bowiem wiele różnych modeli i nie ma sensu spierać się, który z nich lepiej, a który gorzej, który z nich wierniej, a który bardziej niedbale odzwierciedla istotę „czynu samego w sobie”, bo żaden jej nie odzwierciedla. Zob. J. Majewski, Prawnokarne przypisanie..., s. 32. Por. także M. Rodzynkiewicz, Modelowanie pojęć w prawie karnym, Kraków 1998, s. 32. 
odpowiedzieć na wiele różnych sposobów, doszukując się zarówno naturalnych, jak i jurydycznych wyznaczników takiej tożsamości ${ }^{16}$. Beznadziejność poszukiwań na pierwszej z wymienionych płaszczyzn w sposób najbardziej dobitny i trafny uświadomiła często przywoływana wypowiedź Mariana Cieślaka, że

w rzeczywistości obiektywnej nie ma czynów w postaci jakichś odrębnych, oddzielonych od siebie aktów. Istnieją tylko tak czy inaczej zachowujący się ludzie, i to ich zachowanie się, będące przecież wyrazem ich nieprzerwanej egzystencji, jest pewną ciągłością, złożoną z najróżniejszych zlewających się z sobą przejawów aktywności i bierności („,działań” i „zaniechań”). W tej ciągłości, którą można przyrównać do rzeki lub taśmy filmowej, dopiero obserwator (a może być nim nawet sam podmiot zachowania) wyróżnia interesujące go fragmenty (wycinki), tak jakby wycinał klatki w taśmie filmowej, i nazywa je czynami ${ }^{17}$.

Popularność przywołanej tutaj, niezwykle zresztą często cytowanej, wypowiedzi mogłaby sugerować, że obecnie zdajemy już sobie sprawę z dość oczywistego faktu, iż w zachowaniu postrzeganym jako continuum nie ma, niestety, obiektów, które stanowić mogłyby przednormatywną (ontologiczną) podstawę prawnokarnego wartościowania. Jeśli więc dzielimy zachowanie na jakieś podlegające ocenie fragmenty, to tylko dzięki temu, że sięgamy do kryteriów normatywnych ${ }^{18}$. Zresztą już samo wyodrębnienie czegoś, co nazywamy fragmentem ludzkiego zachowania, wymaga zastosowania tego rodzaju kryteriów ${ }^{19}$. Odpo-

16 Wszelkiego rodzaju kryteria, będące podstawą wyodrębnienia czynu jako obiektu prawnokarnego wartościowania, w tym sensie nawiązują do rzeczywistości, że pozwalają na jej rekonstrukcję (są ontologicznej natury), choć jednocześnie stanowią narzędzie służące do kształtowania czy modelowania rzeczywistości (mają zatem charakter ewidentnie normatywny). O ile jednak o kryteriach służących do określania istoty czynu możemy powiedzieć, że po części zmierzają one do samej tylko rekonstrukcji tego, co faktycznie zaistniało, częściowo zaś rzeczywistość tę również kreują, o tyle kryteria będące podstawą wyznaczania granic czynu mają już wyłącznie normatywne podłoże, albowiem brak w rzeczywistości jakichkolwiek ,punktów zaczepienia", które ułatwiałyby odpowiedź na pytanie, gdzie i kiedy czyn się zaczyna lub kończy.

17 M. Cieślak, Polskie prawo karne. Zarys systemowego ujęcia, Warszawa 1994, s. 148-149; idem, Recenzja książki L. Kubickiego „Przestępstwo popetnione przez zaniechanie. Zagadnienia podstawowe”, PiP 1977, s. 2, s. 125 n.

18 To w procesie typizacji czynu zabronionego dochodzi - jak dobitnie podkreśla J. Majewski — do „odcięcia” tego właśnie fragmentu działalności potencjalnego sprawcy, który ma być relewantny z punktu widzenia odpowiedzialności karnej; nie jest to nic innego jak ustalenie granic czynu na potrzeby odpowiedzialności tego rodzaju. J. Majewski, ,Ten sam czyn”..., s. 43

19 Zgodnie z zyskującym od pewnego czasu dość wyraźną przewagę poglądem, o tożsamości czynu decydują kryteria normatywne, albowiem w rzeczywistości nie istnieją obiekty, które moglibyśmy nazwać czynami, przy czym kryteriów tych poszukiwać należy wyłącznie w wynikającym z ustawowej typizacji opisie zabronionego zachowania. To znamiona typu — zwłaszcza zaś te, które charakteryzują czynność sprawczą - są podstawą selekcjonowania fragmentu zachowania podlegającego prawnokarnemu wartościowaniu. Przy takim ujęciu czynem staje się więc to, co ustawodawca uzna za czyn. Trafnie zauważa P. Kardas, że „negując możliwość wyznaczania w oderwaniu od regulacji ustawowych tożsamości czynu, przesądza się, że tym samym czynem jest to, co wycięte zostaje z continuum zachowania się człowieka przez znamiona typu czynu 
wiedź na pytanie dotyczące kwestii ilościowej, a więc na pytanie ,jakie są granice czynu oraz czy w poddawanym prawnokarnemu wartościowaniu fragmencie ludzkiego zachowania dałoby się wyodrębnić jeden lub więcej niż jeden czyn" ma przeto ewidentnie normatywne zabarwienie.

Przyglądając się praktyce wymiaru sprawiedliwości, dojść można do — skądinąd złudnego - wniosku, że wyodrębnienie fragmentu zachowania, w którego ramach (granicach) sprawca realizuje znamiona składające się na jedną tylko typizację, to zadanie relatywnie proste. Punktem początkowym jest w takim przypadku moment, w którym rozpoczyna się realizacja znamienia czasownikowego, natomiast punkt końcowy to, przykładowo, jeśli w rachubę wchodzi przestępstwo materialne, wystąpienie ustawowo określonego skutku. Ponieważ, co łatwo zauważyć, kryteria normatywne, jakich dostarcza przepis ustawy karnej, „nakładamy” na rozgrywające się w czasie i przestrzeni zachowanie podmiotu, to poszukiwaną tutaj tożsamość uzyskujemy na osi czasu. Mówiąc inaczej — z owego nieprzerwanie dziejącego się continuum selekcjonujemy fragment obejmujący zachowanie realizowane od jakiejś chwili początkowej $t_{1}$ do jakiejś chwili końcowej $t_{2}$.

Sytuacja zaczyna się, niestety, komplikować, wówczas gdy w ramach wyodrębnionego na osi czasu fragmentu zachowania dochodzi do realizacji znamion innego typu czynu zabronionego. Kryteria tożsamości czynu stają się bowiem jeszcze bardziej zawodne i prowadzą niekiedy do rodzących wątpliwość rezultatów, gdy złożone (bo wynikające z konkurujących typizacji) okazują się kryteria jego prawnokarnego wartościowania, a więc gdy wyodrębniony fragment ludzkiego zachowania wiązany jest z realizacją znamion co najmniej dwóch różnych typów przestępstw. Rzecz mianowicie w tym, że jeśli w obrębie zachowania poddanego prawnokarnemu wartościowaniu stwierdzimy naruszenie dwóch norm sankcjonowanych, to nie zdołamy, niestety, uniknąc pytania, w jakiej relacji fragment zachowania będącego naruszeniem jednej $\mathrm{z}$ tych norm pozostaje do fragmentu zachowania stanowiącego naruszenie drugiej z nich. W rachubę wchodzą wówczas — co do zasady — cztery możliwości, a mianowicie: oba fragmenty w pełni się na siebie nakładają, fragment dłuższy zawiera się we fragmencie krótszym, oba fragmenty tylko częściowo się pokrywają, a więc pozostają w relacji krzyżowania, oba fragmenty nie mają żadnych punktów stycznych.

Wskazując wymienione tutaj relacje w doktrynie i judykaturze, zauważano niekiedy, że jedynym w miarę pewnym kryterium tożsamości czynu w przypadku realizacji znamion co najmniej dwóch przepisów ustawy karnej staje się ich

zabronionego. W zależności od kształtu znamion raz będzie to zintegrowany, skondensowany w miejscu i czasie akt działania lub zaniechania, raz złożona konfiguracja różnorodnych przejawów aktywności lub pasywności. Powiązanie ich w jedną całość przy pomocy znamion typu czynu zabronionego oznacza zarazem, że stanowią one łącznie i niepodzielnie jeden przedmiot prawnokarnego wartościowania, ten sam czyn w rozumieniu art. $11 \S 1$ k.k., art. $6 \S 1$ k.k.s. czy art. 17 § 1 k.p.k.”. Zob. P. Kardas, Zbieg przepisów..., s. 148. 
zbieżność czasowa ${ }^{20}$, jakkolwiek daje się jednocześnie zauważyć zupełnie zrozumiały niedosyt, jaki rodzić musi opieranie tożsamości czynu na stwierdzeniu, że realizacja znamion miała miejsce $\mathrm{w}$ tym samym czasie, czyli — mówiąc inaczej - okazała się całkowicie lub częściowo jednoczesna ${ }^{21}$. Na wielu przykładach można by wykazać, że samo stwierdzenie, iż kryteriów tych dostarcza nam przepis ustawy karnej, gdyż o tożsamości czynu decyduje wynikający z przepisu opis czynu zabronionego, jawi się przeto jako niewystarczające. Niewystarczająca wydaje się również koincydencja oznaczająca czasowe nakładanie się fragmentów zachowań naruszających różne przepisy. Fakt, że sprawca w tym samym czasie (a więc od jakiejś chwili początkowej $t_{l}$ do jakiejś chwili końcowej $t_{2}$ ) zrealizował znamiona dwu lub więcej przepisów, sam przez się nie powinien prowadzić do wniosku, że ich realizacja była jednoczynowa. Swoistą niekonsekwencją raziłoby także upatrywanie podstawowego kryterium tożsamości czynu, będącej wszak tożsamością kreowaną (normatywną) w ustaleniu opartym na weryfikowalnym przecież (obiektywnym) fakcie, że zachodzi zbieżność czasowa czy — mówiąc inaczej — nakładanie się fragmentów zachowania podmiotu, odpowiadających znamionom co najmniej dwóch typów czynu zabronionego. Dość osobliwa była-

20 Tożsamość czasu zdaje się w sposób szczególny eksponować P. Kardas, o czym świadczyć może następująca wypowiedź: „Przyjmując za podstawowe kryterium tożsamości czynu znamiona czynnościowe określające zachowanie karalne, na gruncie tego ujęcia można przyjąć, że z identycznością (tożsamością) czynu mamy do czynienia zawsze wówczas, gdy określony wycinek continuum zachowania się sprawcy poddawany prawnokarnemu wartościowaniu daje się uznać w pewnym fragmencie za relewantny z punktu widzenia jednej normy sankcjonującej, z wielością (różnorodnością) zaś wówczas, gdy inny fragment, niepokrywający się w żadnej części z pierwszym, daje się wartościować z punktu widzenia innej normy sankcjonującej. Brak będzie jednak podstaw do przyjęcia wielości czynów (braku tożsamości) w sytuacji, gdy określony wycinek continuum zachowania się sprawcy, poddawany prawnokarnemu wartościowaniu, dający się uznać w pewnym fragmencie za relewantny z punktu widzenia jednej normy sankcjonującej, będzie wartościowany także z punktu widzenia innej, treściowo różniącej się normy sankcjonującej. Jeżeli w odniesieniu do obu norm będzie to ten sam kompleks uzewnętrznionych ruchów, niekoniecznie pokrywających się, lecz zawsze mieszczących się w wyznaczonych ramach, wówczas zachodzi identyczność (tożsamość) czynu, do którego konkurują dwie lub więcej normy sankcjonujące". Zob. ibidem, s. $142 \mathrm{n}$.

21 W literaturze spotkać można m.in. pogląd, że ten sam kompleks ruchów może stanowić tylko jeden czyn, bez względu na wielość skutków, brak tożsamości pokrzywdzonego czy brak tożsamości dobra prawnego. W przypadku wielości zachowań decydujące znaczenie ma tożsamość czasu, pokrzywdzonego i zamiaru sprawcy. Pomocnicze znaczenie może mieć tożsamość miejsca i dobra prawnego. Por. W. Wróbel, A. Zoll, Polskie prawo karne. Część ogólna, Kraków 2013, s. 285. Pomijając już w tym miejscu dyskusyjność każdego ze wskazanych kryteriów, można by zadać pytanie, na jakiej podstawie mielibyśmy odróżniać ten sam kompleks ruchów od sytuacji, w których wykonywane przez podmiot ruchy tworzyć miałyby co najmniej dwa różne kompleksy. Czyżby owa kompleksowość miała mieć charakter obiektywny (przednormatywny) i wynikać $\mathrm{z}$ istoty podejmowanego zachowania? 
by przecież sytuacja, w której o jedności normatywnej decydować miałoby kryterium faktyczne $e^{22}$.

Zdając sobie sprawę, że tożsamość czasu, w jakim realizowane są znamiona — niezależnie jakie znaczenie chcielibyśmy jej ostatecznie nadać, sama przez się o tożsamości czynu raczej nie przesądzi, ulegamy niekiedy pokusie, aby integrowania aktywności sprawcy dokonywać przy uwzględnieniu kauzalnie powiązanego z zachowaniem sprawcy skutku. Nie kryjąc sceptycyzmu co do użyteczności tak ujętego kryterium, przypomnieć od razu należy, że wedle dominującego w doktrynie i judykaturze poglądu o wielości czynów nie decyduje wielość skutków. Przyjmując za podstawę tożsamości czynu kryteria normatywne, w tym w szczególności znamiona czasownikowe, niejako z istoty rzeczy wyklucza się możliwość multiplikacji czynów w związku z wielością występujących w określonych okolicznościach następstw, jakie zostały spowodowane ${ }^{23}$. Oznacza to, że jeśli podmiot wywoła jednym zachowaniem więcej niż jeden skutek, to nie będzie przeszkód, aby całe zdarzenie potraktować jako jeden czyn. Kryterium takie można by całkiem zasadnie kwestionować, wskazując również na wątpliwość wyrażającą się w pytaniu, na jakiej podstawie mielibyśmy ustalać, czy i kiedy mamy do czynienia $\mathrm{z}$ wielością skutków, a nie z jego tożsamością, zwłaszcza jeśli określenie skutku na płaszczyźnie ustawowej okazuje się tak ogólne (np. znaczna szkoda majątkowa ${ }^{24}$ ), że właściwie można nim objąć i tym samym podsumować wiele rozmaitych następstw, jakie wynikają z podjętego zachowania ${ }^{25}$.

22 Nie powinniśmy również tracić z pola widzenia, że stwierdzenie, iż mamy do czynienia z tożsamością czynu lub wielością czynów, jest oceną dokonywaną ex post przez obiektywnego obserwatora (sędziego). Podmiot, którego zachowanie jest oceniane — rozpoczynając jego realizację — nie myśli przecież o nim w kategoriach dających się wyodrębnić obiektów czy też jakichś przedzielonych wyraźnymi granicami fragmentów. Trudno byłoby zatem uznać, że decyzja, czy planowane ex ante zachowanie stanowić będzie jeden lub więcej czynów, miałaby należeć do jego sprawcy, dla którego — z prakseologicznego punktu widzenia — kwestia ta jest najzupełniej obojętna.

23 P. Kardas, Zbieg przepisów..., s. 144-145. Autor ten wprost stwierdza, że wielość skutków nie ma znaczenia z punktu widzenia wyznaczania tożsamości (jedności) czynu. Podobnie również J. Majewski, ,,Ten sam czyn”..., s. 44 n.

24 Jeśli szkoda jest w tym sensie rozproszona, że mówiąc oględnie nie dotyczy jakiegoś jednego składnika majątkowego, to przecież rodzi się od razu pytanie, czy powinniśmy przyjąć, że mamy do czynienia z ujętą sumarycznie, a więc odpowiednio wyższą, lecz za to tylko jedną szkodą majątkową, czy też szkód tych, choć oczywiście niższych, jest odpowiednio więcej.

${ }^{25}$ Okazuje się zatem, że kwestia konkretyzacji skutku oraz badania jego tożsamości jawi się jako problem mocno skomplikowany, poddający się rozmaitym relatywizmom, jakie nieuchronnie wiążą się z przyjęciem określonej perspektywy poznawczej. Gdyby jednak nawet oprzeć się na dość optymistycznym założeniu, że problem jedności (tożsamości) lub wielości skutku udałoby się jakoś rozwikłać, to i tak nie rozwiązalibyśmy w ten sposób wszystkich nasuwających się problemów. Otwarte pozostaje bowiem nadal pytanie, jakie kryteria decydować miałyby o tym, że w ramach jednego czynu uda się powiązać następstwa będące różnymi (a więc wieloma) skutkami określonej aktywności sprawcy. Dostrzegamy zatem, że jedność lub wielość to problem dotyczący obu 
Dążąc do ustalenia, że tym samym (jednym) czynem jest odpowiednio wyselekcjonowany fragment aktywności sprawcy (zwłaszcza wówczas, gdy składa się on z wielu rozmaitych zachowań), nie można oczywiście przeoczyć roli i znaczenia strony podmiotowej w wyznaczaniu tożsamości czynu. Dla integrowania aktywności sprawcy trudno bowiem znaleźć dobre uzasadnienie, jeśli do dalszych rozważań nie włączymy elementów charakteryzujących stan jego świadomości oraz towarzyszące mu procesy wolicjonalne, o ile oczywiście gotowi bylibyśmy zgodzić się z założeniem, że o tożsamości czynu nie może być mowy, jeśli nie pojawi się jakaś okoliczność sytuowana w głowie samego sprawcy, racjonalizująca powiązanie jego aktywności w jedną całość. Na tego rodzaju swoistą funkcję strony podmiotowej zwraca uwagę P. Kardas, podkreślając m.in., że gdy ustawodawca opisuje w sposób złożony zachowanie karalne — co mogłoby oznaczać, iż do realizacji znamion strony przedmiotowej konieczne jest wypełnienie więcej niż jednego fragmentu zachowania lub też możliwa jest (niekoniecznie jednak wymagana) jednorazowa realizacja znamion — to wprowadza warunek objęcia zespołu złożonych działań lub zaniechań umyślnością, która stanowi jedną z przesłanek tożsamości czynu.

Brak tej komponenty przesądza o dekompletacji warunków tożsamości czynu. Znamiennym przykładem tego typu konstrukcji ustawowej jest instytucja czynu ciągłego, stanowiąca podstawę wyznaczania tożsamości czynu i wykreślenia obejmującego wszystkie popełnione w przedziale od początku pierwszego do końca ostatniego, spięte klamrą ciągłości zachowania, stanowiące jedno zdarzenie historyczne, jeden niepodzielny przedmiot procesu ${ }^{26}$.

O tym, że ocena dotycząca tożsamości lub wielości czynów - zwłaszcza gdy mamy do czynienia z wielością naruszonych przepisów — wymaga bardziej rozbudowanych oraz precyzyjniejszych kryteriów normatywnych, z łatwością można się przekonać, analizując praktykę orzeczniczą ${ }^{27}$. Analiza ta pozwala zauważyć, że, niestety, również praktyce nie udało się wskazać kryterium innego niż „nakładający się” czas realizacji znamion co najmniej dwóch różnych typów przestępstw, choć jego poszukiwania szły w różnych kierunkach. Ich efekt trudno jednak uznać za udany oraz przekonujący. Dobrym przykładem jest tutaj wy-

ogniw łańcucha kauzalnego (czyli zachowania/zachowań oraz skutku/skutków), które próbujemy integrować. Gdzie zatem szukać spoiwa, dzięki któremu wiązalibyśmy je w jakąś sensowną całość? Por. J. Giezek, Niedopetnienie obowiązku lub nadużycie (przekroczenie) uprawnienia a tożsamość czynu zabronionego, [w:] Na styku prawa karnego i prawa o wykroczeniach. Zagadnienia materialnoprawne oraz procesowe. Księga Jubileuszowa dedykowana Profesorowi Markowi Bojarskiemu, red. J. Sawicki, K. Łucarz, t. 1, Wrocław 2016, s. 126.

26 P. Kardas, Zbieg przepisów..., s. 146-147.

27 Gdy się głębiej zastanowić nad analizowanym tutaj zagadnieniem, to cały kłopot z nim związany zdaje się polegać na tym, że sferę faktów obejmującą zachowanie podmiotu, na które nakładany jest model prawnokarnego wartościowania, mieszamy zazwyczaj ze sferą prawa, w której pojawia się odpowiednio wypreparowane pojęcie czynu, stanowiące podstawę tego modelu. 
powiedź Sądu Najwyższego zawarta w uzasadnieniu postanowienia z dnia 28 marca 2002 roku (I KZP 4/02). W podstawowej tezie tego judykatu czytamy, że zachowanie sprawcy kierującego pojazdem w stanie nietrzeźwości lub po użyciu środka odurzającego, który w następstwie naruszenia zasad bezpieczeństwa w ruchu powoduje wypadek komunikacyjny, stanowi dwa odrębne czyny zabronione — jeden z art. 178a § 1 lub 2 k.k., drugi zaś z art. 177 § 1 lub 2 k.k. w związku $\mathrm{z}$ art. $178 \S 1 \mathrm{kk}$. W tym konkretnym przypadku tożsamość czasu (w znaczeniu nakładania się czasu realizacji znamion przestępstwa z art. 178a k.k. na czas realizacji znamion przestępstwa $\mathrm{z}$ art. 177 k.k.) oceniona więc została nie tyle jako niewystarczająca, ile raczej jako zupełnie obojętna lub mogąca wręcz prowadzić do niewłaściwych wniosków. Powołując się na obszerne w tym zakresie rozważania licznych przedstawicieli doktryny ${ }^{28}$, Sąd Najwyższy przypomniał natomiast, że przyjmowane są dwie zasadnicze grupy kryteriów, których spełnienie waży na ocenach o możliwości przyjęcia (lub o odrzuceniu takiej możliwości) jedności czynu, a mianowicie:

- kryteria subiektywne (nastawienie sprawcy, zmierzające do osiągnięcia tego samego, relewantnego z punktu widzenia prawa karnego, celu);

— kryteria obiektywne (w szczególności zwartość miejscowa i czasowa ocenianego wydarzenia; wyodrębnienie zintegrowanych zespołów aktywności sprawcy).

Abstrahując już od tego, że żadne ze wskazanych — powiedzmy to otwarcie — wysoce niejasnych, a przy tym dających się relatywizować kryteriów, zdaniem Sądu Najwyższego w rozpoznawanym przypadku nie wystapiło, zdumiewać musi konstatacja, że o prawnej (a więc przecież nie ontologicznej) jedności czynu decydować miałyby tego rodzaju okoliczności faktyczne, jak: zmierzanie do tego samego celu, zwartość miejscowa i czasowa czy wyodrębnienie zintegrowanych zespołów aktywności sprawcy. Gdyby tak określone kryteria miały decydować o tożsamości czynu, to byłaby to zapewne tożsamość faktyczna, a nie jurydyczna, co w konsekwencji stanowiłoby potwierdzenie poglądu zazwyczaj (i chyba nie bez racji) odrzucanego, zgodnie z którym w rzeczywistości istnieją takie obiekty jak czyn. Inspirująca wydaje się natomiast zawarta w wypowiedzi Sądu Najwyższego sugestia, że o wielości czynów decydować może wielość naruszanych reguł postępowania ( $\mathrm{w}$ analizowanym przypadku — różnych zasad bezpieczenia ruchu), choć jednocześnie zaskakują rozważania na temat związku przyczynowego o bezpośrednim charakterze jako — czego można się domyślać — poszukiwanego tutaj kryterium ${ }^{29}$.

28 Wskazano tam w szczególności prace W. Woltera, Reguty wyłączania wielości ocen w prawie karnym, Warszawa 1968; A. Spotowskiego, Pomijalny (pozorny) zbieg przepisów ustawy i przestęstw, Warszawa 1976; M. Tarnawskiego, Zagadnienia jedności i wielości przestępstw, Poznań 1977, oraz podane przez tych autorów dalsze piśmiennictwo krajowe i zagraniczne.

29 Najpoważniejszych przeszkód w przyjęciu tożsamości czynu Sąd Najwyższy upatruje $\mathrm{w}$ analizie zachowania z punktu widzenia kryterium wyodrębnienia zintegrowanych zespołów 
III. Pojawia się pytanie, dlaczego właściwie tak bardzo zależy nam na tym, aby wyznaczyć granice czynu i zakreślić tym samym jego ramy, a w rezultacie — uznać jedność i tożsamość jakiegoś fragmentu ludzkiego zachowania ${ }^{30}$. Trudno oprzeć się wrażeniu, że zabiegamy o to - jeśli nie jedynie, to zapewne przede wszystkim - ze względu na tzw. mechanizmy redukcyjne, powiązane z wielokrotną (co najmniej dwukrotną) realizacją znamion czynu zabronionego, które determinują określony model prawnokarnego wartościowania ${ }^{31}$. Mechanizmy te, nawet jeśli prowadzić mają do określenia ilości obiektów podlegających prawno-

aktywności sprawcy, albowiem istota występku określonego w art. 178a $\S 1$ lub 2 k.k. polega na prowadzeniu pojazdu w stanie nietrzeźwości lub pod wpływem środka odurzającego, co samo w sobie oznacza wypełnienie ustawowych znamion przestępstwa, nawet jeśli pojazd prowadzony był całkowicie prawidłowo. Sąd Najwyższy zwraca jednocześnie uwagę, że nawet jeśli kierowanie pojazdem przez osobę będącą w stanie nietrzeźwości stanowi naruszenie zasady bezpieczeństwa ruchu (zob. np. tezę 7 uchwały pełnego składu Izby Karnej SN z dnia 28 lutego 1975 r., V KZP 2/74, OSNKW 1975, z. 3-4, poz. 33; oraz wyrok składu 7 sędziów SN z dnia 19 kwietnia 1985 r., Rnw 5/85, OSNKW 1986, z. 1-2, poz. 4) - do przypisania przestępstwa tzw. spowodowania wypadku komunikacyjnego konieczne jest także stwierdzenie innych elementów zespołu aktywności (lub bierności). W art. 177 k.k. chodzi o takie zasady, których naruszenie może stanowić bezpośrednią przyczynę skutków wymienionych w tym przepisie, podczas gdy między samym tylko stanem nietrzeźwości a skutkami przewidzianymi w art. 177 § 1 i 2 k.k. nie istnieje związek przyczynowy o bezpośrednim charakterze (zob. A. Gubiński, Glosa do cyt. wyroku SN z dnia 19 kwietnia 1985 r., PiP 1986, z. 9, s. 147). Tak więc aktywność sprawcy polegająca wyłącznie na prowadzeniu pojazdu w stanie nietrzeźwości lub pod wpływem środka odurzającego stanowi występek określony w art. 178a $\S 1$ lub 2 k.k., podczas gdy do odpowiedzialności sprawcy za spowodowanie wypadku komunikacyjnego konieczne jest ponadto stwierdzenie dodatkowego zespołu aktywności, naruszającego inną, konkretną zasadę bezpieczeństwa ruchu, pozostającą w związku przyczynowym z zaistniałym wypadkiem. To właśnie spostrzeżenie prowadzi Sąd Najwyższy do wniosku, że w analizowanym stanie faktycznym mamy do czynienia $\mathrm{z}$ wielością, nie zaś tożsamością czynu.

${ }^{30} \mathrm{~W}$ literaturze trafnie podkreśla się, że właśnie kwestia tożsamości czy też identyczności czynu stanowi najbardziej doniosłe i jednocześnie najtrudniejsze zagadnienie związane z konstrukcją zbiegu przepisów, zaliczone zarazem do najbardziej spornych w doktrynie. Zob. P. Kardas, Zbieg przepisów..., s. 115.

31 Charakteryzując istotę wszystkich wykorzystywanych w prawie karnym mechanizmów redukcyjnych, P. Kardas zwraca uwagę na to, że sprowadza się ona do racjonalizacji procesu prawnokarnego wartościowania i eliminacji w oparciu o odpowiednio ukształtowane przesłanki (ujęte w ustawie lub wypracowane w doktrynie i orzecznictwie, a więc z natury rzeczy pozaustawowe), przypadków nieuzasadnionej kumulacji odpowiedzialności. „Nie chodzi przy tym o jakiekolwiek formy łagodzenia konsekwencji wynikających z określonych zachowań, lecz o zapobieganie przypadkom, w których wykorzystanie określonych konstrukcji prowadziłoby do pozbawionej podstaw i uzasadnienia, naruszającej zasadę sprawiedliwej reakcji multiplikacji dolegliwości wobec sprawcy. Innymi słowy o zapobieganie nieuzasadnionemu wielokrotnemu ukaraniu sprawcy (przypisaniu odpowiedzialności karnej), wielokrotnemu wymierzeniu takiemu sprawcy kar oraz wielokrotnemu, z reguły sekwencyjnemu, wykonaniu orzeczonych kar”. Por. P. Kardas, „,Idealny zbieg przestępstw" jako problem teoretyczny, dogmatyczny i kryminalnopolityczny, CzPKiNP 2014, z. 3, s. 20. 
karnemu wartościowaniu ${ }^{32}$, a więc wskazywać na jedno- lub wieloczynowość, są instrumentami o charakterze normatywnym, stanowiącymi — jak zresztą większość instytucji prawa materialnego - efekt zaakceptowania pewnej konwencji, która zazwyczaj ma niewiele wspólnego z nadającym się do weryfikacji odzwierciedlaniem obiektywnie istniejącej rzeczywistości, a w skrajnych przypadkach rzeczywistość tę nawet całkowicie lekceważy. Stwierdzenie, że mechanizmy redukcyjne wpływać mogłyby również na tzw. ontyczne (obiektywne) podstawy odpowiedzialności karnej, w pewnym sensie byłoby nawet jakąś sprzecznością samą w sobie. Żaden mechanizm redukcyjny nie jest bowiem w stanie zmodyfikować faktycznego zachowania sprawcy, lecz prowadzić może co najwyżej do tego, że w procesie karnym zostanie ono „pokrojone” na krótsze lub dłuższe odcinki, a następnie poddane mniej lub bardziej zintegrowanemu prawnokarnemu wartościowaniu. O tego rodzaju konwencji — niezależnie od jej relacji do rzeczywistości — możemy oczywiście powiedzieć, że jest użyteczna, racjonalna, nadająca się do wykorzystania lub — odwrotnie — że jej użyteczność jest znikoma, a oparte na niej rozstrzygnięcia trudne do sensownego zracjonalizowania. Możemy wszak umówić się co do tego, że zachowania ze z góry powziętym zamiarem stanowią jeden czyn, natomiast ciąg zachowań wykonywanych z zamiarem odnawialnym, choć wykorzystujących taką samą sposobność, to konstrukcja wieloczynowa. Do grupy retorycznych można zaliczyć pytanie, czy groziłoby nam jakieś załamanie podstaw odpowiedzialności karnej, gdybyśmy umówili się odwrotnie, etykietując pierwsze z zachowań jako wieloczynowe, ciąg przestępstw oceniając jako jeden czyn.

Powraca natomiast w tym miejscu zasadnicza wątpliwość, dlaczego gdy poddawany prawnokarnemu wartościowaniu fragment zachowania wiąże się z realizacją znamion co najmniej dwóch różnych typów przestępstw, dostrzegamy potrzebę jakiejś potencjalnej redukcji odpowiedzialności, której fundament stanowić miałoby ustalenie, czy w rachubę wchodzi tożsamość, czy może raczej wielość popełnionych czynów. Odpowiedź prima facie wydaje się prosta. Otóż chodzi nie tylko o zredukowanie ${ }^{33}$, lecz w rezultacie przede wszystkim o zracjonalizowanie prawnokarnych konsekwencji, jakie wynikają niekiedy z wielości naruszonych przepisów. Sceptyk mógłby jednak zauważyć, że przecież wyobrażalny jest taki

32 Warto podkreślić, że mechanizmy redukcyjne są w taki sposób pomyślane, że najpierw stosować należy te, które odnoszą się do redukcji podstaw (obiektów) prawnokarnego wartościowania, następnie te funkcjonujące na płaszczyźnie subsumcji (określające sposób przypisania odpowiedzialności), w dalszej kolejności — odnoszące się do płaszczyzny wymiaru kary, ostatecznie zaś służące do ujednolicenia wielości orzeczonych za wielość przestępstw kar. Zob. szerzej M. Bielski, Normatywne mechanizmy zapobiegajace przyjęciu realnego zbiegu przestępstw jako negatywna przesłanka zastosowania instytucji kary łącznej, [w:] Zagadnienia teorii i nauczania prawa karnego. Kara łączna. Księga Jubileuszowa Profesor Marii Szewczyk, red. W. Górowski et al., s. 405 n.

33 Redukcja nie jest celem samym w sobie. W istocie stanowić ma raczej instrument służący racjonalizacji odpowiedzialności karnej sprawcy co najmniej dwukrotnie naruszającego normę. 
model odpowiedzialności karnej, w którym każda realizacja znamion — niezależnie w jakim czasie następuje — oznaczałaby popełnienie odrębnego przestępstwa, powiązanego z kumulującymi się, a więc w żaden sposób nieredukowalnymi konsekwencjami. Godząc się na taki model, musielibyśmy jednak rozważyć, czy przyjęcie kumulującej się reakcji karnej byłoby — zwłaszcza z kryminalnopolitycznego punktu widzenia — rozwiązaniem racjonalnym. Znaleźlibyśmy z pewnością znacznie więcej argumentów przemawiających za jej stosowną redukcją, a więc przeciwko kumulacji, opowiadając się tym samym za ograniczaniem prawnokarnych konsekwencji w przypadku stwierdzenia w podlegającym prawnokarnemu wartościowaniu fragmencie zachowania realizacji znamion składających się na co najmniej dwa różne typy czynów zabronionych.

Nie zmienia to jednak faktu, że mechanizmy redukcyjne pomyślane zostały w taki sposób, aby u podstaw ich stosowania już na wstępie wyłaniało się pytanie o tożsamość albo wielość popełnionych czynów. Doniosłość tego pytania wynika stąd, że inne mechanizmy prowadzące do zredukowania odpowiedzialności karnej aktualizują się w przypadku jednoczynowej realizacji znamion dwóch co najmniej typów przestępstw, inne zaś wówczas gdy ich realizacja jest wieloczynowa. Różnice dzielące te mechanizmy dotyczą nie tylko, a nawet nie przede wszystkim konsekwencji ${ }^{34}$, lecz także procedur, jakie wiążą się z ich stosowaniem. Łatwo w tym kontekście zauważyć, że gdyby nigdy nie zdarzało się, aby w określonym (relatywnie krótkim) przedziale czasu dochodziło do realizacji znamion dwóch lub więcej przepisów stanowiących podstawę prawnokarnego wartościowania lub gdyby w podlegającym takiemu wartościowaniu fragmencie aktywności podmiotu nie następowała multiplikacja zachowań naruszających normę, to kwestia tożsamości lub wielości czynów radykalnie straciłaby na znaczeniu. Prowadzi to innymi słowy do wniosku, że jeśliby odrzucić wszelkie mechanizmy redukcyjne lub dokonać ich ujednolicenia, to pytanie o jedność lub wielość popełnionych czynów miałoby na płaszczyźnie prawa materialnego wymiar jedynie teoretyczny. O tym zaś, że nie rozważamy obecnie poważniejszych modyfikacji obowiązującego modelu mechanizmów redukcyjnych (a w każdym razie nie próbujemy uniezależnić go od jedno- lub wieloczynowości), zdaje się decydować nie do końca trafne przeświadczenie, że w przypadku odrzucenia tego modelu reakcja karna mogłaby okazać się po prostu niesprawiedliwa.

IV. Zastanawiając się nad sensem oraz uzasadnieniem stosowania mechanizmów redukujących odpowiedzialność karną — przy założeniu, że dążymy do

34 Nietrudno wykazać, że ostateczny rezultat w postaci tzw. kary łącznej, będącej swoistym podsumowaniem realnego zbiegu przestępstw, może in concreto niewiele różnić się od rezultatu, jakim w przypadku jednoczynowego zbiegu kumulatywnego jest kara wymierzona na podstawie przepisu przewidującego najsurowszą sankcję, odpowiednio przy tym zaostrzona $\mathrm{w}$ ramach sądowego wymiaru kary ze względu na zbieg z innymi przepisami. 
tego, aby były one jak najbardziej intuicyjne, a więc zrozumiałe dla przeciętnego adresata prawnokarnych norm postępowania — powiedzielibyśmy zapewne, że przy podsumowywaniu działalności przestępczej tego samego sprawcy z jednej strony liczyć powinna się suma wyrządzonego zła, z drugiej zaś możliwość kumulowania odpowiednio zracjonalizowanej reakcji karnej. Trudno oprzeć się wrażeniu, że wyznaczając ilość zasługujących na taką reakcję obiektów (czynów) w ramach podlegającego ocenie fragmentu zachowania, dość bezrefleksyjnie „szatkujemy” lub „kumulujemy” zło wynikające z naruszenia rozmaitych dóbr prawem chronionych, aby rozparcelować odpowiedzialność karną za jego wyrządzenie. $Z$ tego przede wszystkim względu staramy się wyznaczyć granice obiektów podlegających wartościowaniu oraz określić ich ilość. Rozważając, jaka reakcja karna korespondowałaby z wielokrotną realizacją znamion, nie powinniśmy natomiast tracić z pola widzenia, że jeśli sprawca narusza co najmniej dwie normy (lub dwukrotnie tę samą normę), to — siłą rzeczy — suma wyrządzonego zła jest większa, przy czym dzieje się tak zupełnie niezależnie od tego, czy naruszanie takie ocenione zostanie jako jedno- lub wieloczynowe. Mówiąc zaś inaczej — suma wyrządzonego zła w gruncie rzeczy w najmniejszym stopniu nie zależy od ustalenia, czy oraz ile odrębnych obiektów zwanych czynami zdołamy „wypreparować” w ramach poddawanego prawnokarnej ocenie fragmentu zachowania sprawcy.

Truizmem wydaje się również twierdzenie, że mechanizmy redukcyjne, jakie wchodzą w rachubę w przypadku co najmniej dwukrotnej realizacji znamion czynu zabronionego, pomyślane zostały w taki sposób, aby prowadząc do swoistego podsumowywania działalności przestępczej, powodować załagodzenie odpowiedzialności karnej. Nie trzeba szerzej uzasadniać tezy, że jeśliby prawnokarne konsekwencje, jakie są powiązane z realizacją znamion czynu zabronionego, postrzegać w sposób wyizolowany i nie dopuszczać możliwości ich integrowania czy — jak to się niekiedy określa — redukowania lub podsumowywania obejmującego co najmniej dwukrotną lub dotyczącą co najmniej dwóch typizacji realizację znamion — to w rezultacie odpowiedzialność karna byłaby w zdecydowanej większości sytuacji znacznie surowsza. Można też uznać, dochodząc w ten sposób do sedna omawianego tutaj problemu, że mechanizmy redukujące odpowiedzialność karną znacznie bardziej sprzyjają — przynajmniej teoretycznie oraz na płaszczyźnie rozwiązań ustawowych — tym sprawcom, których zachowanie ujęto w ramy jednego (tego samego) czynu, okazują się natomiast bardziej restrykcyjne w przypadku konstrukcji wieloczynowych. Pojawia się pytanie, jakie miałoby być aksjologiczne uzasadnienie takiego różnicowania mechanizmów redukcyjnych oraz wynikających z nich konsekwencji, a w ślad za nim — w wypadku braku klarownej odpowiedzi — wątpliwość dotycząca tego, czy różnice w tym zakresie odpowiadają niekiedy nawet dość elementarnemu poczuciu sprawiedliwości lub po prostu zwyczajnej intuicji przeciętnego adresata prawnokarnych norm postępowania. 
Wskazaną wątpliwość ilustrować można na wielu różnych przykładach. Jednym z bardziej spektakularnych zdaje się różnicowanie mechanizmów redukcyjnych w wypadku — z jednej strony — jednoczynowej konstrukcji czynu ciągłego, z drugiej zaś - wieloczynowej konstrukcji ciągu przestępstw lub ich realnego zbiegu. Wystąpienie lub brak z góry powziętego zamiaru, którego przedmiot stanowiłaby sekwencja podjętych przez sprawcę czynności, ma wszak sprawiać, że w obejmującym wszystkie te czynności fragmencie zachowania, którego długość jest raczej niezależna od strony podmiotowej, wyodrębnimy odpowiednio jeden lub więcej obiektów zwanych czynami, co z kolei w sposób istotny przekłada się na rodzaj stosowanych mechanizmów redukcyjnych oraz wynikających $\mathrm{z}$ nich konsekwencji.

Sytuacji, w których pojawia się wielość naruszonych przepisów oraz towarzyszące im już na wstępie pytanie o ilość obiektów podlegających prawnokarnemu wartościowaniu, jest oczywiście znacznie więcej, przy czym wcale nie muszą one się wiązać z ciągłością podejmowanej przez sprawcę aktywności. Wyraźnie zróżnicowane są również ich konsekwencje. Doskonale zdajemy sobie przecież sprawę, że mechanizmy redukcyjne znacząco różnić się mogą także wówczas gdy — oceniając skondensowaną w relatywnie krótkim czasie realizację znamion co najmniej dwóch różnych typizacji — w miejsce zbiegu rzeczywistego przepisów zechcemy przyjąć realny zbieg przestępstw lub odwrotnie. Wiadomo bowiem, że w pierwszym wypadku w rachubę wchodzi kwalifikacja kumulatywna oraz odpowiedzialność za jeden czyn, natomiast w drugim — wieloczynowość otwierająca drogę do zastosowania instytucji kary łącznej.

Wyobraźmy sobie dwa warianty zachowania sprawcy popełniającego przestępstwo rozboju, powiązane ze spowodowaniem u pokrzywdzonego ciężkiego uszczerbku na zdrowiu, z których pierwszy polega na prowadzącym do takiego uszczerbku użyciu przemocy i dokonaniu kradzieży, natomiast drugi — nieco bardziej rozciągnięty w czasie — rozpoczyna się od kradzieży poprzedzonej groźbą natychmiastowego użycia przemocy, po czym już po jej dokonaniu staje się wywołującym ciężki uszczerbek spełnieniem wcześniejszej groźby. Uwzględniając wypowiedzi doktryny i judykatury na temat kryteriów tożsamości czynu lub jej braku, bez obawy o popełnienie błędu można by przyjąć, że w pierwszym przypadku zastosowanie znajdzie jednoczynowa konstrukcja kumulatywnego zbiegu przepisów, natomiast w drugim — konstrukcja realnego zbiegu przestępstw, zwłaszcza jeśli zamiar spełnienia wcześniejszej groźby zostałby podjęty już po dokonaniu kradzieży. Patrząc z perspektywy uwzględniającej aspekt aksjologiczny, trudno w sposób racjonalny uzasadnić zróżnicowanie prawnokarnej oceny dwóch porównywanych, a jednocześnie bardzo podobnych fragmentów zachowania, prowadzącego wszak do pogwałcenia tych samych norm (wynikających z przepisów art. 280 k.k. oraz 156 k.k.) oraz do naruszenia takich samych dóbr prawnych (czyli 
mienia, wolności i zdrowia), a różniących się — w sposób skądinąd mało znaczący - jedynie chronologią zdarzeń ${ }^{35}$.

Otóż wszystkie wskazywane komplikacje, potencjalnie prowadzące do rozstrzygnięć wysoce nieintuicyjnych, by nie powiedzieć niekiedy wręcz niedorzecznych, zdają się mieć swe źródło w usilnym zabieganiu, aby w poddawanym prawnokarnej ocenie fragmencie zachowania sprawcy wyodrębnić wedle rozmaitych kryteriów (niestety nie zawsze odzwierciedlających poziom jego społecznej szkodliwości) jeden lub więcej obiektów, nazywanych czynami. Mogłoby się wydawać, że dążenie takie zdeterminowane jest potwierdzoną przez ustawodawcę zasadą, w myśl której ten sam czyn stanowić może tylko jedno przestępstwo, przeciwstawianą zasadzie idealnego zbiegu przestępstw. Rzecz jednak w tym, że to nie o zbieg realny albo idealny w tym miejscu chodzi. Łatwo zauważyć, że akceptując zasadę idealnego zbiegu przestępstw, wcale nie uniknęlibyśmy problemów, jakie wiążą się z poszukiwaniem kryteriów pozwalających na wyznaczenie granic obiektu prawnokarnego wartościowania, nazywanego czynem. Niezależnie bowiem od tego, czy uznamy, że jeden (ten sam) czyn stanowić może tylko jedno przestępstwo, czy też - jak przy zbiegu idealnym — oznacza on wielość przestępstw (odpowiadającą wielości naruszonych przepisów), najpierw musimy rozstrzygnąć, czy mamy do czynienia z jednym, czy może raczej z wieloma obiektami poddawanymi prawnokarnemu wartościowaniu. Wszak idealny zbieg przestępstw właśnie dlatego postrzegany jest jako idealny, że jego podstawą jest ten sam czyn. Odrzucenie konstrukcji realnego zbiegu przepisów nie zwalniałoby nas zatem $z$ obowiązku wyznaczenia jego granic. Nie powinniśmy również tracić z pola widzenia, że zarówno nazwa „,zbieg idealny”, jak i kryjąca się za nią merytoryczna treść straciłyby jakikolwiek sens, gdyby nie udało się wyodrębnić stanowiącego jego podstawę czynu. Dylemat nie sprowadza się więc do tego, czy przyjąć zasadę jednoczynowego zbiegu przepisów, czy idealnego zbiegu przestępstw, lecz wyraża się w pytaniu, czy w przypadku wielości naruszonych przepisów dałoby się w sposób racjonalny i sensowny zaprojektować mechanizmy redukujące odpowiedzialność karną bez potrzeby wyodrębniania — w ramach poddawnego prawnokarnej ocenie fragmentu zachowania sprawcy - obiektów nazywanych czynami.

Nieuchronnie nasuwa się w tym kontekście wątpliwość, czy podstawą oceny prowadzącej do podsumowania i sensownego zredukowania aktywności przestępczej sprawcy (mającej wszak ewidentnie normatywny charakter) powinna być

35 Przyznać jednak należy, że pomimo zaktualizowania się dwóch zupełnie innych mechanizmów redukcyjnych wymierzona ostatecznie kara (orzeczona jako jednostkowa lub łączna) może na poziomie jej sądowego wymiaru okazać się pod względem surowości bardzo podobna, choć przecież wcale tak być nie musi, zwłaszcza że uruchomienie procedury związanej z wymierzaniem kary łącznej (w przypadku przyjęcia konstrukcji dwuczynowej) co do zasady sprzyja zaostrzaniu represji karnej. 
tożsamość lub wielość obiektów zwanych czynami, wyznaczana niestety na podstawie kryteriów tylko pozornie znormatywizowanych ${ }^{36}$. Dlaczego naruszenie więcej niż jednego dobra prawnego miałoby być wartościowane w zależności od tego, na jakie fragmenty (wzajemnie nakładające się lub wykluczające) podzielona została aktywność sprawcy? Uzasadniona wydaje się również wątpliwość, czy podstawę mechanizmów redukcyjnych stanowić ma jedno- lub wieloczynowość, definiowana wedle kryteriów, które - zamiast ułatwiać ocenę zachowania sprawcy — nawiązują do pewnych uwarunkowań faktycznych, jak chociażby jego zwartość miejscowa i czasowa. Jako znacznie atrakcyjniejsze i lepiej zracjonalizowane jawi się wszak założenie, że podstawą tych mechanizmów powinny być kryteria na wskroś normatywne, wzorowane przykładowo na tych, które wykorzystujemy w modelu obiektywnego przypisania skutku. Nie powinniśmy również tracić z pola widzenia, że pytanie o tożsamość czynu pojawia się przecież na wstępnym etapie, $w$ istocie poprzedzającym jego wartościowanie, czyli już wówczas gdy dostrzeżona zostanie możliwość zakwalifikowania podlegającego ocenie fragmentu zachowania z co najmniej dwóch różnych przepisów. Chcąc bowiem zastosować właściwy mechanizm redukcyjny, staramy się ustalić, czy zmultiplikowana (a ściślej - co najmniej dwukrotna) realizacja znamion była jedno- czy wieloczynowa. Jeśli zaś głębiej nad tym zagadnieniem się zastanowić, to z punktu widzenia oceny zachowania ujmowanego jako continuum kwestię tożsamości lub wielości obiektów podlegających wartościowaniu można by w zasadzie pominąć, albowiem nie ma ona wpływu na kryminalną zawartość bezprawia.

Rozwijając nieco zarysowywaną tutaj propozycję uniezależnienia mechanizmów redukcyjnych od jedno- lub wieloczynowości, można, przykładowo, sięgnąć do jednego z kluczowych elementów modelu obiektywnego przypisania, jakim jest stworzenie nieakceptowalnego ryzyka wystąpienia negatywnego skutku, czy też — jak twierdzą niektórzy — naruszenie obowiązującej w obrocie reguły postępowania z dobrem prawnym. Łatwo zauważyć, że poziom (natężenie) owego ryzyka nie zależy od ilości obiektów, jakie wyodrębnimy w zachowaniu podmiotu. Dość oczywiste wydaje się też spostrzeżenie, że ryzyko generowane określonym fragmentem zachowania może mieć różne źródła (genezę) oraz charakter. Prawnokarnej oceny zachowania nie musimy zatem wiązać z ilością podlegających takiej ocenie obiektów, jakie uda się wedle skądinąd bardzo niejasnych kryteriów

36 Znamiona typu, które decydować miałyby o tym, jaki fragment zachowania zostanie wyselekcjonowany jako podlegający prawnokarnemu wartościowaniu obiekt, w przypadku konkurencji przepisów same przez się nie ułatwią przecież ustalenia, jaka jest ilość tego rodzaju obiektów. Rzecz przy tym charakterystyczna i poniekąd zaskakująca, że kwestię związaną z jakością zachowania zwanego czynem wiążemy z kryteriami o charakterze częściowo normatywnym (wykonalność, dowolność), podczas gdy kwestia ilościowa, bo dotycząca tożsamości lub wielości czynów, miałaby już opierać się przede wszystkim na tego rodzaju kryteriach, jak zwartość czasowo-przestrzenna, a więc nawiązujących do okoliczności faktycznych, w jakich zachowanie jest realizowane. 
ostatecznie w ocenianym fragmencie wyodrębnić, o wiele ważniejsze wydaje się natężenie nieodpowiedniości tego zachowania, będące m.in. pochodną ilości oraz natężenia wygenerowanych ryzyk. Mogłoby to prowadzić do wniosku, że modelu mechanizmów redukujących odpowiedzialność nie powinniśmy uzależniać od ilości popełnionych czynów, lecz raczej od tego, ile źródeł ryzyka sprawca wygenerował ocenianym fragmentem zachowania, czyli innymi słowy od ilości naruszonych reguł postępowania z dobrem prawnym. Dałoby się chyba podjąć próbę sformułowania oceny opartej na liczbie naruszonych reguł postępowania, która zawierałaby odpowiedź na pytanie, czy w ramach poddawanego prawnokarnemu wartościowaniu fragmentu zachowania sprawca wygenerował tylko jedno źródło owego ryzyka, czy też źródeł tych jest więcej.

Można oczywiście postawić zarzut, że tożsamość ryzyka lub wielość wygenerowanych przez podmiot ryzyk, czyli innymi słowy ich jedno- lub wieloźródłowość to podstawa mechanizmów redukcyjnych co najmniej równie nieprecyzyjna jak jedno- lub wieloczynowość. Chodzi tutaj jednak - po pierwsze - o pewną zasadniczą myśl, że to nie liczba obiektów nazywanych czynami decydować powinna o prawnokarnym wartościowaniu zachowania sprawcy, lecz zasadnicze znaczenie mieć musi liczba naruszonych reguł postępowania z dobrami prawnymi, wpływająca na ilość oraz natężenie wygenerowanych ryzyk, na jakie dobra te będą narażone. Po drugie - mimo wszystko łatwiej na płaszczyźnie normatywnej ocenić liczbę naruszonych reguł oraz wiążącą się z nimi ilość ryzyk niż wyodrębnić wedle kryteriów znacznie mniej klarownych (a przy tym uzależnionych od w gruncie rzeczy nieistotnych faktów) liczbę popełnionych czynów. Po trzecie wreszcie - powiązanie mechanizmów redukcyjnych ze stwarzanym przez podmiot ryzykiem w przeciwieństwie do ich uzależniania od ilości popełnianych czynów otwiera możliwość porównywania nie tylko ilości źródeł, z jakich wywodzi się ryzyko dla dobra prawnego, lecz także jego jakości i natężenia.

Gdyby ten ogólnie sformułowany postulat — aby to nie ilość czynów, lecz ilość wygenerowanych przez sprawcę ryzyk (oraz towarzyszących im zazwyczaj naruszeń reguł postępowania z dobrem prawnym) legła u podstaw modelu mechanizmów redukcyjnych — to prawdopodobnie mechanizmy te musiałyby ulec dość znaczącej modyfikacji. Nawet wstępne naszkicowanie takiego modelu przekracza niestety ramy tego opracowania. Oczywistą $i$ chyba raczej pozytywną konsekwencją tego rodzaju przebudowy byłaby natomiast możliwość rezygnacji z pojęcia czynu jako wyselekcjonowanego z continnum obiektu prawnokarnego wartościowania o precyzyjnie wyznaczonych granicach. Nie deprecjonując roli rzeczywistego zachowania podmiotu jako tzw. ontologicznej podstawy jego ewentualnej odpowiedzialności karnej, można jednak zaryzykować pogląd, że znaczenie pojęcia czynu w prawie karnym jest obecnie dość mocno przereklamowane. 


\section{The Identity of an act as a basis for differentiation of mechanisms reducing criminal responsibility}

\section{Summary}

Our starting point is the view, well grounded in the dogmatics of criminal law, that the separation of a criminal offence as an entity judged from a legal standpoint is based upon both ontic and normative criteria. On the one hand, the basis for an act, anchored in reality, is the behaviour of a subject, on the other hand, what part of it we consider a single object of legal judgement is decided by the legislator. The situation becomes more complicated whenever the judgement of a particular part of a subject's behaviour is determined by the realisation of the features of at least two prohibited acts. The criteria of unity of an act - apart from full or partial identity of time, in which at least two sets of features of prohibited acts are realised, are highly vague. One could probably refrain from searching for them, has it not been for the fact that the presence of a single act - or multiple acts - is the basis for the currently binding model of reduction mechanisms. If those mechanisms were to rationalise criminal liability, the basis of their use should consist of entirely normative criteria, based, for example, on those that we use for objective ascription of the result. A model of mechanisms of this kind could be determined by the quantity and quality of the violated rules of conduct, or, to use a different phrase, the multiplicity of sources of risk generated by the subject. A positive consequence of such rearrangement could be the possibility of abandoning the concept of an act as an object of legal judgement, selected from the continuum of behaviour, with a precisely determined timeframe.

Keywords: behaviour, act, criteria of identity of an act, reduction mechanisms, rules of conduct. 